\title{
Problems of modeling further development of civil legislation of the Russian Federation
}

\author{
Mikhail Semyakin ${ }^{1}$, Larisa Dobrynina ${ }^{1, *}$, Anna Gubareva ${ }^{1}$ and Lubov Gudovicheva ${ }^{1}$ \\ ${ }^{1}$ Ural State Law University, 21, Komsomolskaya st., 620137, Ekaterinburg, Russia
}

\begin{abstract}
The article provides of civil modeling of civil legislation development, shows its significance and peculiarities, structural elements, gives their characteristics, concludes the necessity of an integrated approach to Problem of civil models. For a long time, and to a large extent now, legislation, including civil law, is perceived as a means of legal regulation of public relations, and normative legal acts are considered mainly as the most important legal form of fixing and ensuring the proper conduct of the subjects. This "normative" approach, along with the positive ones, also contains a number of negative aspects, when there is a deep analysis of the draft legislation, the possibility and consequences of their implementation in practice, which often leads to the fact that the effectiveness of many normative acts remains low; there are many conflicts and cases of inconsistency in legislation; changes, additions and other, sometimes unsystematic, amendments to the legislation that give rise to a lot of discussions in the scientific and practical environment are constantly being made.
\end{abstract}

\section{Introduction}

Civil law is not only a form of reflection and a means of legal regulation of relevant public relations, but also an important instrument of cognition and transformation of civil social reality.

This makes it necessary to know its state, modern tendencies of civil-legal regulation, to study possibilities of advanced legal influence, to develop models of development of civil legislation, etc. That will adequately take into account the role of economic, sociocultural, political and other factors in the process of legal modelling.

Recently in the theoretical jurisprudence there were works in the sphere of modeling, in particular, it concerns the detailed scientific research of $Y u$. A. Tikhomirov, devoted to modeling of legal phenomena[1].Considering the abovementioned, we are supposed to put a number of ideas down. The civil law models are a powerful tool that makes possible optimization of civil law understanding, lawmaking and law applicationactivity as law and order in the sphere.

What is a civil law model? It is the predicted optimal variant of civil-legal regulation of corresponding property, personal non-property and other civil relations, providing the purpose, tasks and means of achievement of the certain state of civilrelations in the given

\footnotetext{
*Corresponding author: dovre@yandex.ru
} 
sphere, and also allows to make calculation of achievement of desirable social effect. A civil law model is supposed to reflect not only state of civil law and order, but also prospects of its development that is more important, taking into account economic, sociocultural, political trends, etc. In addition, a civil law model should reflect interaction (not only) between the state of civil law and order and another regulation means of civil-law social relations including non-legal regulation.

\section{Materials and methods}

A civil law model includes a number of structural elements such as the following.

First, a civil law model is a conceptual basis, reflecting goals and tasks, epistemological and ontological features of civil-law modelling, its principles, general stages of development, wishful socioeconomic and civil-law, etc. effect.

So, for example, in paragraph 6.2 of the "Concept of the development of civil legislation of the Russian Federation" [2], it is drawn attention to the fact that (in the legislative order) by law two basic models of proprietary rights to land plots should be fixed: 1) the right of superficies, that suppers the qualitychanse of the land, primarily the erection of various structures on it; 2) the right of permanent possession and use (emfitevzis), which assumes ample oppotunities of using the properties of a natural object while preserving its substance. Both models of these rights give their owners the right to ownership and use of the land plot.

In this regard, the current concept of the development of civil legislation of the Russian Federation has been criticized. In the literature, it was noted that the reasoning of the developers of the named concept are built, roughly, on such a model: once in practice there are some or other relations which are not directly provided in the legislation, then, therefore, it is necessary to quickly supplement it with the appropriate statute (legal provision).

However, for the conceptual position as an element of the civil law model, it appears that thesementioned above circumstances are clearly insufficient. It is necessary, at least briefly, to show the gnoseological aspect of this problem: what is the essence (nature) of the arisen phenomenon, whether it is a natural or random character for the civil order and, accordingly, and whether it is necessary, and whether it could be regulated at the legislative level; what is its axiological (value) aspect; the most optimal legal structure which can be chosen in this regard; what socio-economic, legal and other effects such a supplement can provide to legislation; which goal is achieved, and so on, and not just mechanically follow the practicethat in a number of situations may be random or even incorrect, which has unfortunately occurred repeatedly in our civil reality.

Second, another important element of civil-law model is cleardefinition of the subject matter, its limits and substance of the prospective civil-law regulation. The interdependence between the elements inside the civil-law system and other ones as links with economic, sociocultural, psychological, etc. aspects and necessity of their consideration in civil-law model is essential.

In particular, in the circle of relations regulated by the civil legislation and defining its subject (article 2 of the Civil Code of the Russian Federation), the legislator in 2014 [3] includes corporate relations-relations on creation of corporate type legal entities and their management. The updated edition of the Civil Code of the Russian Federation sufficiently clear establishes the circle of relations that are part of the subject of civil law: it is not only obligatory and reallegal relations, but also allocated to a special category of relations related to the definition Legal status of participants of civil circulation (referred to as "organizational and property" [4]), relations connected with the occurrence and exercising of intellectual rights, and, finally, corporate relations, that are not mixed with other types of property and non-property relations [5]. 
Third, unconditionally, there should be aspects determined such as legal, economic, etc. foundations, legal prohibitions and prescriptions, their correlation and combination that supposed to be (stated) in favour ofsubjects of civil law that makesconferring the rights prefominancepossible to analyseprospective trends of civil law, its particularinstitutions, legislative and another normative legal acts, their potential effectiveness.

Recent innovations instituted in the Russian Civil Code include a number of provisions concerning the strengthening of the compensatory function of civil legislation, whithatch put emphasis not so much on civil liability, but rather on the maintenance of Stable civil turnover. In 2015, the Russian Civil Code was supplemented by novels designed to introduce into the Russian obligations right tools traditionally used in the structuring of treaties on English law [6].

This concerns the emergence of such institutions in the Civil Code of the Russian Federation, as estoppels (article 166), astreinte (art. 308.3), break-up fee (art. 310), termination fee (art. 310), injunction (art. 393), indemnity (art. 406.1), warranties (art. 431.2), opposabilite du contrat (art. 433), waiver (art. 450.1) and others. Despite the foreign nature for the Russian legal system, first of all, Anglo-Saxon experience, these institutions are a given of our Civil Code.

Such a position of the legislator was sufficiently constructive criticized in scientific circles. It was noted that rules pulled from the root of another legal system would never yield the desired results in foreign conditions. We have our own legal traditions, our own unique legal system, incompatible with any system of law relating to the Anglo-Saxon legal family. For Russian law, reckless copying and imitation inevitably can result in many problems in law enforcement practice [7].

Forth, a civil-law model must contain assessment of generally recognized principles of international law andnorms of international treaties of the Russian Federation, that in accordance are constituents of the Russian legal system (with paragraph 1 of article 7 of the Civil Code of Russian Federation). This aspect is especially important in regulation of civil (social)relations when one of the parties is a foreigner sincein case of conflict of international law with national legislation generally recognized principles and standards of international law are of primary importance.

Art. 15 of the Constitution of the Russian Federation[8] enshrines the primacy of international law over national. All the years the principle of the supremacy of international law has been so absolutized that the issue of its revision was not raised either in the domestic legislative activity, or even in science, which a priori should question everything. As a result, if happened as the Chairman of the Constitutional Court of the Russian Federation V. Zorkin very precisely called devaluation, that is depreciation of national law in relation to the law international.

At the same time, the question of the contradiction between the norms of international common law and national legislation, for example, in the U.S. Constitution is not regulated at all. The problem is undertaken at the whim of the judiciary and is very flexible, and is addressed taking into account national interests. The priority of national law is established in Brazil, India, North Korea.

As A. Bastrykin points out, law can not exist by itself, that is for the sake of law. It is a tool of influence, which is filled with a certain ideological content-a legal idea, which, however, always has an applied character. Geopolitical, strategic, economic interests and even particular fundamental beliers may not coincide in different countries. And attempts to introduce into states foreign values through international law, as experience has shown, often lead not to the unity of States, but to even greater contradictions [9].

In this respect, it should also be said that in 1998 the Russian Federation ratified the "Convention for the Protection of Human rights and fundamental freedoms"[10], recognizing it as an integral part of its legal system. By ratifying the agreements, the country recognized 
the jurisdiction of the European Court of Human Rights (ECHR) and committed itself to the implementation of its decisions.

The Constitutional Court at the request of the State Duma deputies checked the legality of the European Court of Human Rights decisions in the Russian Federation and whether they have the ultimate goal of blurring the borders of the Russian sovereignty. The decision was made, Russia has the right not to implement the decisions of the European Court of Human Rights if they go against the Constitution of the Russian Federation [11].

However, these correlations do not imply a departure from the fundamental principles of international law. On the contrary, Russia seeks to take into account in its legislation the legal institutions of private international law. In this connection, most of the innovations of the Civil Code of the Russian Federation are adopted on the basis of the analysis of the application of relevant norms by international arbitration courts, decisions within the UNIDROIT and the European Union.

In the world, the intensive development of conflicts of regulation is being further developed. This process has not been bypassed by Russia. Amendments to section VI of the Russian Civil Code "international private Law" affect quite a wide range of relations, correlate a number of conflict rules to achieve greater adequacy of regulation and improve a number of provisions of the law in terms of juridical technique.

Fifth, undoubtedly, civil law modelling embraces activity of subjects of civil law (social) relations, especially of subjects in business, their legal status, and causes the necessity of legal, organizational, economic, etc. means and measures for reaching the positive results. In 2014-2018 the Russian Civil Code was supplemented by the rules on public joint stock companies (art. 66.3 of the Russian Civil Code), the rules on the possibility and consequences of the challenge of illegal reorganization of legal entities (art. $57-60.2$ of the Russian Federation), the system of rules on book-entry securities ( $\S 3$ Ch. 7 Russian Civil Code), about decisions of meetings (Ch. 9.1 of the Russian Civil Code), about "metal accounts" and the deposit agreement of precious metals (article 844.1, article 859.1 of the Russian Civil Code), etc.

Sixth, analysis of civil law subjects'behaviour including positive as well as negative behaviour, reasons and circumstances causing deviant behaviouras an element of civil law modelling is of great importance. On the issue, civil law is in dire need of exact indicators, measures that will make it possible to assess subject's behaviour of any kind as right (effective) or on the contrary as wrong (non-effective) or neutral in order to apply corrective actions.

It should be noted the introduction of the principle of good faith in civil law as one of the principles of civil law (article 1, paragraph 4, of the Russian Civil Code), specification deprived of legal protection "Forms of abuse of law", Introduction to the Russian Civil Code of the Institute Precontractual liability on the principle of "culpa in Contrahendo", transformation of most of the rules on the invalidity of transactions ( $\S 2 \mathrm{Ch} .9$ of the Russian Civil Code), clarification of the rules on the statute of limitations/ prescription period (article 195 of the Civil Code of the Russian Federation), etc. In the sphere of corporate law the shared responsibility/jointaud several liability of persons constituting the body of a legal entity (item 3 of article 53 of the Civil Code of the Russian Federation), the possibility of "withdrawal of corporate veil" (article 56 of the Russian Civil Code), etc.

Seventh, risk analysis in civil law field as an element of civil law modelling deserves particular attention, especially taking into account that risk is a inalienable feature of business. On such circumstances, there should be foreseen more flexible economic, legal, etc. means of optimum risks allocation among relevant civil law subjects, effective mechanisms of insurance losses indemnity, appearing because of insured events.

In 2013, during the reform of the regulatory system in the financial market, the Bank of Russia was entrusted with the function of developing the main directions of the financial 
market development of the Russian Federation. The Bank of Russia has developed a document with a cross-sectoral character describing the planned actions of the Bank of Russia on development of all sectors of the financial market till 2020. The Bank of Russia and the legislator have taken a number of steps to improve the system of investor protection in the financial market, to counteract the financial pyramids and fraudulent actions, to provide cross-border services, etc.[12]

In any model of legal regulation not only the position of the legislator is embodied and the directions of development of legal relations are reflected, their forecasting for long decades. It assumes the conservativeness and sustainability of the development of the society on the proposed in the normative acts "program". One of the fundamental directions is fixed in ch. 1 art. 7 of the RF Constitution, according to which the Russian Federation is a social state whose policy is aimed at creating conditions that ensure a dignified life and free development. The underlying in its frameworklegal equality of the parties does not preclude the provision of certain guarantees by the State to citizens as the economically weak side of many relationships[13]. On the basis of these beginnings, it should be noted that a number of draft legislative acts offered by private persons/ individuals and independent experts are far ahead of modern legal thinking, going beyond the established, including the global legal model.

This is primarily the concept of copyright in the digital environment (called "internet tax"), proposed by filmmaker N. Mikhalkov, which could radically change the world model of the regulation of copyright and related rights. This draft concept of the global license would introduce a new mechanism for charging fees for the use of copyright-protected materials on the network. It was planned that fixed fee from operators of cellular and Internet communication, will charge the organizations managing copyright and related rights on a collective basis, depending on number of subscribers. Then, the money was distributed among the right holders (authors, owners of related rights, etc.). According to the project, each Internet user would have to pay on average 25 rubles per month for access to all legal content. Each subject could freely download and use all that is on the Internet, it is literature, movies, music, etc. However, this project was subjected to massive criticism of show business representatives, for whom this project is initially unprofitable [14]. The amounts they receive for infringement of intellectual rights far exceed the income they would receive through the introduction of the system in the country.

Eighth, the civil model should take into account public elements in civil law. The balance of private and public elements should take into account the achievements of the European doctrine of private law, the domestic realities reflected in judicial practice. Of course, civil law is a right private, law and the public-legal method of regulation should prevail in it, that does not exclude the use of means of influence of the state (administrative, criminal) law, provided by the relevant Legislation.

In the common interest of all participants in civil trafficking, in the interests of society as a whole, the influence of the state and both as a legislator and as a judicial authority on the maintenance and state of civil law and order in the country, in the last few years, was significantly strengthened.

Any model of legal regulation (civil, process, administrative, penal) is subordinated to the general policy of the State and mediates the goals achieved by it. In accordance with government-mandated action plans ("road maps"), a number of normative acts have been amended to improve the quality of public services in the areas of: state registration of rights to real estate [15], urban planning activities [16], transport policy [17], elimination of seizures and restrictions on the domestic market [18], optimization and abolition of mandatory requirements in the field of trade [19], procedures for the registration of legal entities and individual entrepreneurs [20], etc. 
The civil model is part of a large-scale model of legal regulation within the Russian state. The increase of administrative component in the policy of state influence is partly caused by political and economic sanctions of the USA and the European Union against Russia in 20142018 years. As a response to special economic measures against the West, it is prohibited or limited to the implementation of foreign economic operations, providing for the import into the territory of the Russian Federation of certain types of agricultural products, Raw materials and foodstuffs, the country of origin of which is the state, accepted the decision on imposing economic sanctions against Russian legal and (or) natural persons or acceded to such a decision [21].

Ninth, the model of Civil regulation should be plastic and receptive to new, constantly emerging and updating tendencies, which take place in the international economic turnover, to adequately regulate relations about new Phenomena, processes and objects, taking into account both private and public interests.

In order to use the key world technologies and the latest information technologies to improve the quality of life and business conditions, by the order of the Government of the Russian Federation the program "digital Economy of the Russian Federation" was approved [22]. As a result, by the summer of 2018 the concept of creation and development of $5 \mathrm{~g}$ networks in Russia should appear, the establishment of national and regional Centers for response to computer incidents, stimulation of import and control Processing and access to personal data of Russians, in particular, including social networks, legal regulation will receive blockchain, artificial intelligence, augmented reality, etc [23].

The BRICS countries (where Russia is a member) discussed the possibility of creating cryptocurrency as an alternative to other payment instruments at the domestic and interstate level [24]. The legislator monitors the cryptocurrency market and develops approaches to the definition and regulation of cryptocurrency in the Russian Federation. Most transactions with private "virtual currencies" (cryptocurrencies) are performed outside the legal field of the Russian Federation and most other countries. In Russia, along with the preparation of the draft federal law "On digital financial assets"[25] on the legalization of the turnover of cryptocurrency, published explanations of the Bank of Russia-the main regulator in this area, which confirmed its principled negative Position on cryptocurrencies [26].

The Bank of Russia notes that transactions in the cryptocurrency system are made anonymously, there is no specific obligated person and centralized control. The anonymity of payments motivates the use of virtual currency for committing crimes, including drug, weapons, terrorist financing, tax evasion [27]. The Civil model of regulation is directly related to economic relations, trying to subject them to proper legal regulation. But practice is always ahead of the legal reality. Thus, according to expert estimates, the volume of turnover of money surrogates in Russia already reaches $1 \%$ of the gross domestic product. By exceeding this index by more than $10 \%$, this instrument will pose a real threat to the financial stability of the State [28].

\section{Results}

This way, only complex using of legal, economic, organizational, etc. means of civil relations regulation may favourthe development of effective civil law models of civil law development, its separate institutions, legislative acts and making a right choice of civil law model. The choice is to be based on projection data assessment and on results of analytic scientific research of such the decision that it to be appropriate for prospective civil, economic, sociocultural, etc. requirements of social development.

The above-mentioned gives us a basis for drawing a conclusion that the nature of such models has a complex character. However, given one looks at considered phenomenon from another angle id estwithout any formal aspects like functions and significance of every 
structural element we are able and necessary to state, on such circumstances, that civil law development models has united civil nature. The conclusion is based on the statement economic, organizational, sociocultural, and psychological and other instruments as elements of a civil law model have auxiliary (subsidiary) function, not independent. It favoursa civil law model that is under development to consider civil law social relations of any kind, their distinct features in complex interaction and interconnection between them, relations development trends. he main purpose is prospective construction of civil law reality and all the functions including auxiliary ones favours it by using synergetic effect of cognition of civil law model, its structural elements and coherence of them as difficult enough social legal system.

What are the objects of civil law modelling? Obviously, there is hardly necessity and reasonability intaking a try to make a model of civil law actions, decisions, distinct civil law relations and juridical facts, etc. since there is a great deal of things like these in civil law reality. In addition, the construction process of the civil law reality as well as any social one is quite resource consuming (materials, time, intellectual labour, etc.). Y.A. Tkihomirov fairly notes that peculiarity of law model objects is in their strategic significance for lawmaking and law application and in their complexity [29].

From these positions, objects of civil law modelling may be the following:

a) reform of civil law overall;

b) reform of civil law in the largest and most important fields of civil reality - intellectual rights, rights in rem, securities market, supply of goods, performance of work, service provision for state and municipal needs, general provisions on obligations;

c) improvement of legislation on particular civil law institutions - mortgage, credit, accounting relations, service provision, protection of the right and legitimate interests of consumers, etc.;

d)development of the Civil Code as systemically important fundamental legislative act;

e) development of another important laws in civil law field - the Consumer Protection Act, the Insolvency Law, the Law on Mortgage, the Housing Construction (Joint Participation) Law;

f) legal monitoring of actions and effectiveness of civil legislation implementation.

The above-mentioned and other similar objects of civil law modelling development find their expression in specific juridical form as conceptions and programs of general ways of development, etc. It makes them reasonable and significant juridical decisions and drafts for developing civil law and the civil law reality.

For these purposes, scientific studies can have large significance, for instance: a) civil theories, such as Conception of civil law development; b) development doctrines on privatelaw policy in Russia; c) conceptions of private- and public-law interests combination in the regulation of civil law social relations; d) substantiation of new civil law institutions; research of new complex inter-branch normative institutions; long-term socioeconomic development programs of the state, e.g. "Russia - 2020", etc.

\section{Conclusions}

Civil law development models, alongside with some common formally structured aspects are distinguished by large scale of content variety: purposes and tasks of modelling, relevant measures and means of reaching them, subjects taking part in model development, monitoring processes of effectiveness of models implementation. E.g. a model of law development in the field of intellectual rights taking into account its content differs much from a development model of construction a new law institution on rights in rem and from prospective corporate law modelling, etc. 
One should not approach civil law modelling from the standpoint of using common typical forms and procedures, lawmaking stages and the text law perception as only a system of symbols containing certain information. It is necessary to take into consideration the features of civil law regulation, interdependence between civil law means of effect on social relations and another means of regulation as legal, economic, organizational, sociocultural, of philosophical vision, psychological and other factors, etc. In addition, in this view we can single out two groups of correlation: a) cause-and-effect relations and interdependence inside the civil legal system (between its institutions and other structural elements), b) interconnection between the civil law means of effect on social relations and the public-law means and other non-legal social regulation instruments.

Only the deepest cognition and consideration of the above-mentioned aspects and processes is able to develop synergetic prospects of using the complex of different kind of legal and other instruments in the process of development modelling of civil reality.

\section{References}

1. O.A. Hakobyan, N. Vlasov, S.A. Grachev, Modeling of legal phenomena. Legal Models and Reality (INFRA-M, Moscow, 2016)

2. A.L. Makovskiy, The concept of development of civil legislation of the Russian Federation (Statut, Moskow, 2009)

3. Federal law of December 30, 2012 № 302-FZ (2013), http://www.consultant.ru/cons

4. V.V. Dolinskaya, Laws of Russia: experience, analysis, practice 6, 3-4 (2015) http://www.consultant.ru/cons

5. E.D. Tyagay, Laws of Russia: experience, analysis, practice, 11 (2016) http://www.consultant.ru/cons

6. A. Chumakov, Corporate lawyer 7, 42 (2015) http://www.consultant.ru/cons

7. L.Yu. Vasilevskaya, Judge, 10 (2016) http://www.consultant.ru/cons

8. Constitution of the Russian Federation, http://www.consultant.ru/cons

9. A. Bastrykin, Rossiyskaya Gazeta - Federal issue, 6661(90) https://rg.ru/2015/04/28/bastrykin.html

10. Convention for the Protection of Human Rights and Fundamental Freedoms (2004), http://www.consultant.ru/cons

11. Resolution of the Constitutional Court of the Russian Federation of 14.07.2015 No 21-p

12. URL: http://www.consultant.ru/cons

13. Resolution of the Constitutional Court of the Russian Federation of 03.07.2001 N 10-P,

14. URL:

https://www.rbc.ru/technology_and_media/30/10/2014/54520724cbb20f5c95a7f876?fr om=materials_on_subject

15. Decree of the Government of the Russian Federation No. 2236-r (2012) http://www.consultant.ru/cons

16. Order of the Government of the Russian Federation No. 1336-r, http://www.consultant.ru/cons

17. Decision of the Eurasian Intergovernmental Council No. 3 (2017) http://www.consultant.ru/cons

18. Order of the Eurasian Intergovernmental Council of 25.10.2017 No. 17, http://www.consultant.ru/cons 
19. Russian Plan of measures ("road map") for updating, optimizing and abolishing mandatory requirements in the sphere of trade" (approved by the minutes of the meeting of the Project Committee No. 61(11), http://www.consultant.ru/cons

20. Order of the Government of the Russian Federation No. 317-r dated 03.03.2013

21. Decree of the President of the Russian Federation of 06.08.2014 No560,

22. Order of the Government of the Russian Federation of July 28, 2017 No. 1632-r ,http://www.consultant.ru/cons

23. Russia in the trend of world technological changes, https://gov-news.ru/pocсия-втренде-мировых-технологических-изменений/

24. URL: https://ria.ru/world/20170904/1501701967.html

25. Draft Federal Law "On Digital Financial Assets" (prepared by the Ministry of Finance of Russia), http://www.consultant.ru/cons

26. E. Sidorenko, A. Saveliev, A. Pushkov, The law, 9 (2017) http://www.consultant.ru/cons

27. Information of the Bank of Russia of 04.09.2017, http://www.consultant.ru/cons

28. A. Bastrykin, Rossiyskaya Gazeta- Federal, 6874(6) (2017)

29. URL: http://www.consultant.ru/cons 